\title{
The Boomerang Age from Childhood to Adulthood: Emergent Trends and Issues for Aging Families
}

\author{
Barbara A. Mitchell \\ Dept. of Sociology/Anthropology \\ and Dept. of Gerontology \\ Simon Fraser University \\ Burnaby, British Columbia, Canada
}

\begin{abstract}
:
From a historical, cross-comparative, life course perspective, this paper examines changing family-related transitions to adulthood and emergent trends and issues for aging families. Primary focus is placed on Canadian families, although comparisons will be made with several Western industrialized countries (U.S., Britain, France, Italy, Sweden). Using nationally representative data, key findings reveal a general extension of young adulthood, in addition to continuation, diversity and reversibility of family behaviours. Future patterns are also explored, in light of other socio-demographic and socio-economic change. It is concluded that aging families of the future will likely display elements of both modified individualism and increased diversification.
\end{abstract}

Key Words: Family transitions, aging families, intergenerational relations 
Barbara A. Mitchell

\section{Résumé :}

Cet article examine les transitions familiales au stage adulte et les tendances et problèmes qui émergent dans les familles vieillissantes selon trois perspectives : le parcours de vie, la biographie et l'analyse comparative. Le focus est principalement placé sur les familles canadiennes bien que la comparaison est aussi faite avec plusieurs états occidentaux industrialisés (les États-Unis, la Grande-Bretagne, la France, l'Italie et la Suède). D'importantes conclusions émergent des données représentatives à l'échelle nationale et révèlent une prolongation générale du stage du jeune adulte, ainsi qu'une continuation, une diversité et une réversibilité des comportements familiaux. Les tendances futures sont explorées dans le cadre d'autres changements socio-démographiques et socio-économiques. Il a été trouvé que les familles vieillissantes du futur auront tendances à manifester des éléments d'individualisme modifié ainsi qu'une plus grande diversité.

Mots-clés : les transitions des familles, les familles vieillissantes, les relations intergénérationnelles

\section{Introduction}

It is well established that the period between childhood and adulthood has become prolonged for many segments of the population in most Western, industrialized societies. Young adults are taking longer to establish themselves residentially, financially, in adult work roles, as well as to form their own families (e.g., see Settersten, Furstenberg, and Rumbault, 2005). Modern-day transitions to adulthood are also deemed to be less permanent and subject to reversibility, leading to conceptualization of young adults as "adultescents" and members of "the boomerang age" (Mitchell, 2006). It is also widely-known that industrialized nations are undergoing profound transformation, due to such factors as population aging, shifting immigration and fertility patterns, and widening inequality for vulnerable groups. Taken together, these patterns have ignited grave concern over the future of aging families, a worry that stems from two assumptions.

One key concern centres on the idea that the transition to adulthood in contemporary times is fraught with unpredictability, confusion, and complexity as life courses become more individualized (e.g., Beck, 2000; Mortimer and Larson, 2002). This "problematization" of youth conception is deemed to affect not only young people but also their intergenerational relationships. This is 
The Boomerang Age from Childhood to Adulthood:

Emergent Trends and Issues for Aging Families

because middle-generation parents are increasingly called on to invest more in their dependent, young adult children while experiencing their own sets of challenges as aging adults. And, since the population is rapidly ageing and undergoing other change (such as declining fertility), another concern is that aging families will increasingly experience a double (or triple) burden of problems as they simultaneously try to meet the needs of competing generations.

However, it is also argued that this negative view of the "overburdened" aging family is based on "apocalyptic" or "voodoo" demographic thinking that is more ideological than factual (e.g., see Gee and Gutman, 2000). In other words, it is asserted that the notion that recent changes in family life invariably have catastrophic consequences for youth, society and intergenerational relations has been "oversold." In response to this ongoing debate, this paper will examine the changing transition to adulthood in conjunction with other population and cultural patterns in order to identify emergent trends and issues for aging families.

The primary emphasis will be placed on Canadian patterns since the 1950s, although fluctuations over the past century will be noted in order to uncover themes of continuity, diversity, and social change. Comparisons to other Western industrialized nations will also be made so that we can situate these trends within a broader context of macro-level structural change. The paper will then explore how current patterns are likely to shape aging family patterns of the future, in recognition of shifting economic and socio-demographic environments.

\section{The Life Course Perspective}

This paper adopts a life course theoretical approach (e.g., Giele and Elder, 1998; Elder, 1995, 1998, 2003; Hareven, 1996; Marshall and Mueller, 2003), which has its roots in several disciplines, notably sociology, demography, history, developmental psychology, and economics. It is useful for studying lifelong agerelated processes and family-related transitions to adulthood and how these intersect with changing family, education, work, welfare, and technological spheres. From this perspective, family-related transitions and relationships are co-constructed by individuals and institutions and are embedded within a particular time and place. The family is seen as a micro social group within a macro social context, or a collection of individuals who interact within everchanging social and economic contexts (Bengston and Allen, 1993: 470).

The life course is defined as a sequence of roles, statuses and transitions that begin in childhood and end with death or in old age. Transitions are envisioned 
as discrete life changes or events, such as leaving the parental home, becoming a parent or getting married. Life course events, such as homeleaving and marriage are also subject to reversibility, such as in the case of returning home as a "boomerang kid" or in divorce. Furthermore, there is diversity with respect to the timing of transitions, which can occur across time, geographical region, and within families. Regional locale can reflect unique social or community contexts that provide constraints or opportunities related to education, jobs, and family formation. Diversity within families is due to multiple bases of inequality and access to social and economic resources, and is social structured by such characteristics as gender, age, ethnicity, immigration status, religious affiliations, and socio-economic status.

A key principle of the life course perspective is the concept of "linked lives." This idea relates to the fact that our lives are not lived in isolation, but are experienced interdependently in aging families. Decisions about when to leave home, for example, are shaped by, and shape the actions of those to whom we are closely tied. Applied to the present study, the decision to leave home, cohabit or marry, for instance, is assumed to affect intergenerational relations, or relationships between parents in the family of origin and their children. It is also assumed that the timing and circumstances of these transitions can contribute to intergenerational solidarity, or it can create ambivalence, conflict, stress or strain. This is because events in the life of one family member create counter transitions (Burton and Bengtson, 1985) or a "ripple effect" (Hagestad, 1991).

Finally, many life course theorists explore popular social theorists' (e.g., Beck, 2000) assumptions of complexity and uncertainty in contemporary family life relative to previous family life. Visions of traditional family life are often glorified in the stereotypical "1950s" family, characterized by predictable, stable, and relatively permanent family patterns. Socio-demographic change (i.e., population aging, immigration patterns), processes of globalization, and a decline of the welfare state in most industrialized societies are thought to create new risks of unparalleled dimensions.

These conditions alter choices and opportunities over the life span and contribute to delayed transitions, such as the increasing need for post-secondary education in industrial societies. They also set in motion a number of consequences for aging families, since the middle-generation is increasingly confronted with new generational tasks, such as simultaneously caring for dependent adult children and elderly parents. Overall, a life course theoretical perspective allows us to address and evaluate "alarmist" or apocalyptic concerns, as well as social change and future implications for aging families. 
The Boomerang Age from Childhood to Adulthood:

Emergent Trends and Issues for Aging Families

\section{Data and Methods}

Data are drawn from nationally representative secondary data sets from each respective country. Specifically, data were gathered to document and compare the timing of the key family-related transitional behaviours under study leaving home, returning home, cohabitation, age at marriage, maternal age at first birth, and crude divorce rates. These population-based data are collected from many different sources. Notably, Canadian data are compiled with a heavy reliance on Statistics Canada sources, such as from the Dominion Bureau of Statistics, the Census and the General Social Survey, the United Nations, as well as some other secondary historical sources (e.g., Gee, 1982; 2000). American data originate from several large-scale surveys, such as those carried out by The National Centre for Health Statistics and the U.S. Census Bureau. European data (including some Canadian and American data) originate from organizations such as: Eurostat, the United Nations Economic Commission for Europe and the Council for Europe (see Mitchell, 2006 for complete detail).

It is recognized that while these data permit us to ascertain general trends over time, there are also many limitations with respect to their accuracy. First, not all secondary data sets have complete historical records. Secondly, American data is sometimes based on median rather than mean averages, making crosscomparative analysis difficult. Third, many of the surveys are cross-sectional and therefore do not reflect cohort change over time. It would be ideal to use statistical methods such as life event analysis to analyze these data, given that this technique is able to estimate the probable timing for those not yet exposed to a particular event.

Furthermore, these data only provide broad brush strokes of each population under study. This makes it difficult to establish patterns of diversity within countries, which are shown to be highly variable across social classes, gender, racial and ethnic groups (Settersten, 2005). Moreover, many measures are relatively "crude." For example, in the case of comparing crude divorce rates, these rates generally yield low rates because they are affected by the population structure. This is because the denominator includes every one in the population, many of whom are not at risk of divorce, since they are children, single, or already divorced. 
Barbara A. Mitchell

\section{Findings: Historical and Contemporary Trends}

\section{Leaving the Parental Home and Boomerang Kids}

Since the 1970s, today's young people in Canada, the U.S., Britain, France, Italy, and Sweden are increasingly leaving home at later ages (Mitchell, 2006). In Canada, 58 percent of young adults aged twenty to twenty-four and 23.7 percent of those aged twenty-five to twenty-nine were living in a parental home in 2001. These rates have risen over the past two decades. For instance, 41 percent of Canadian young adults aged twenty to twenty-nine lived with their parents in 2001, a jump from 27 percent in 1981 (Statistics Canada, 2002).

Similarly, in the U.S. and in Europe, there is a general tendency for young adults to coreside in parental homes longer (e.g., see Corijin and Klijzing, 2001). Yet, variations show a geographical gradient, with lower median ages in Northern Europe (i.e., Sweden), while leaving home occurs much later in Southern countries such as Italy. In fact, Italy displays the latest median ages, with at least 90 percent of young men and women aged eighteen to twenty-four lived with their parents in 2002. This compares to only about 45-60 percent in countries such as Britain and France (Mitchell, 2006). Moreover, living at home past the age of 30 is relatively rare in all countries under study, with the exception of Italy, whereby 7 out of 10 Italian men under the age of 35 still live in the parental home, a phenomenon dubbed "mammoni" (Pike and Allen, 2002).

Although detailed comparative historical data are unavailable, there is ample evidence to suggest that later ages of homeleaving (relative to our mid-century benchmark) also occurred in earlier times. In particular, many North American and European young people often left home quite late during tough economic times, such as during the Great Depression. It has been estimated that in Canada, the average homeleaving age was about twenty-four for men born between 1910 and 1920 (leaving 1930-40) and about twenty-two for women (Ravanera, Rajulton, and Burch, 1992), ages that are actually higher than those in contemporary times.

Extended coresidence is also the result of young people returning home as "boomerang kids," typically defined as leaving and returning for a minimum of a four-month spell. In Canada, recent 2001 Census data show that 28 percent of young women and 33 percent of young men aged 20 to 29 have returned once after an initial departure (Statistics Canada, 2002). This trend of "circular migration" is particularly common in the United States, with $40 \%$ of young adults returning to home (Goldscheider and Goldscheider, 1999). In Europe, 
The Boomerang Age from Childhood to Adulthood:

Emergent Trends and Issues for Aging Families

estimates range from $20 \%$ in France and Sweden to $27 \%$ in Britain, while estimates are not available for Italy, probably due to its relatively low occurrence (e.g., see Mitchell, 2006 for explanations).

Although data are sparse, it appears that the home returning trend as a distinct phenomenon is more common now than in earlier times. For example, using retrospective General Social Survey data (2001), Beaupré, Declos, Milan and Turcotte (2003) find that the probability of home returning was more prevalent among those born between 1977-81 compared to those born between 1932-36. In addition, American research, establishes that the tendency to return home as boomerang kids is a contemporary phenomenon of unprecedented significance that meets young adults' social and economic needs, and is tied to the prolongation of adult work and family roles (e.g., see Goldscheider and Goldscheider, 1999). Conversely, prior to the 1950s, it was less prevalent and more apt to occur to meet the needs of aging parents in the absence of state supports or to meet the needs of both generations simultaneously.

\section{Partnership Formation: Cohabitation and Marital Transitions}

Although heterosexual non-marital cohabitation is usually viewed as a "new" phenomenon, it has actually existed long enough to pre-date marriage ( $\mathrm{Wu}$ and Schimmele, 2003). Yet, we do know that it was relatively rare among North American and in many European countries born before 1940 and that it did not increase substantially until the 1970s. In Canada, from 1981 to 2001, the proportion of common-law families increased from $5.6 \%$ to $14 \%$, and an estimated $56 \%$ of young adults aged twenty to twenty-four now live commonlaw (Vanier Institute of the Family, 2002). Cohabitation is also more common in some regions than in others, such as Quebec, whereby $30 \%$ of all couple families are living common-law (Statistics Canada, 2002). Unfortunately, data on same-sex cohabitation has only recently been collected in Canada, making it difficult to provide comparative patterns on this phenomenon.

With regard to Europe, there is large variation in the propensity to cohabit. Similar to Canada, cohabitation among those aged 25 to 34 is relatively common in France, with $31 \%$ currently cohabiting. Intermediate levels are found in Britain (18\%), and in Canada (18.5\%), whereas Sweden and Italy represent two extremes at $39 \%$ and $8 \%$ respectively. Relatively low rates are reported in the U.S. (7.2\%), however, it is asserted that this estimate underrepresented the true number because only householders and their partners are tabulated, rather than all unmarried couples present in the household. Moreover, there may be a tendency for individuals to classify themselves as roommates, or friends not related to one another (Fields and Casper, 2001). 
Barbara A. Mitchell

\section{Marital Transitions and Parenthood: Timing of Marriage and (Maternal) Age at First Birth}

Figure 1 reveals how the timing of (heterosexual) marriage for men and women and the timing of first (maternal birth) has changed over time in Canada between the 1950s and 2002. Since the 1950s, we observe a trend toward later ages of marriage and the timing of a first birth. For example, in 2001, the average age of first marriage was 27.6 for women and 29.6 for men (Statistics Canada, 2003a). This compares to 23.8 in 1951 for women and 26.6 for men in 1951. With respect to parenthood, first-time mothers were on average, 29.5 years in 2001, up almost five years from 1970 (Statistics Canada, 2004).

In Europe, there is diversity in average ages of marriage and parenthood, although the general trend is toward postponement of these roles. In 2000, for instance, the oldest mean age at first marriage for males occurs in Sweden (32.4), followed by Britain (30.4), Italy (30) and France (29.7). Interestingly, mean ages tend to cluster within a three year age span between the ages 29 to 32 for men and 27 to 30 for women, with the exception of the U.S. (e.g., 26.8 for men), which reports slightly lower ages for both sexes, but also uses median estimates.

Yet, similar to homeleaving trends, a longer range historical view suggests that young people are reverting back to marital and parenthood behaviours characteristic of young people almost a century ago, since average ages were quite high at that time in most industrialized countries. Indeed, age at first marriage and first birth began to rise during the difficult economic times of the 1930s and 1940s. Moreover, the current trend toward having children outside of marriage, in conjunction with recent declines in the marriage rate was also a trend witnessed in earlier periods. For example, the proportion of women who never married by the age of 45 to 49 in 1900 was not that dissimilar from the percentage who never married in 2000 (with the exception of Sweden). Also, Britain exhibits a much higher percentage of never marrieds in 1900 at 17 percent, compared to only 8 percent in 2000 (Mitchell, 2006: 38).

\section{Partnership Dissolution}

Figure 2 shows the crude divorce rates for Canada and the other selected countries of interest since 1950. Italian data do not exist until 1975, at which time divorce became legal. Generally, we see a rise in these crude rates over time, although they have generally stabilized or declined in many countries. In 
The Boomerang Age from Childhood to Adulthood: Emergent Trends and Issues for Aging Families

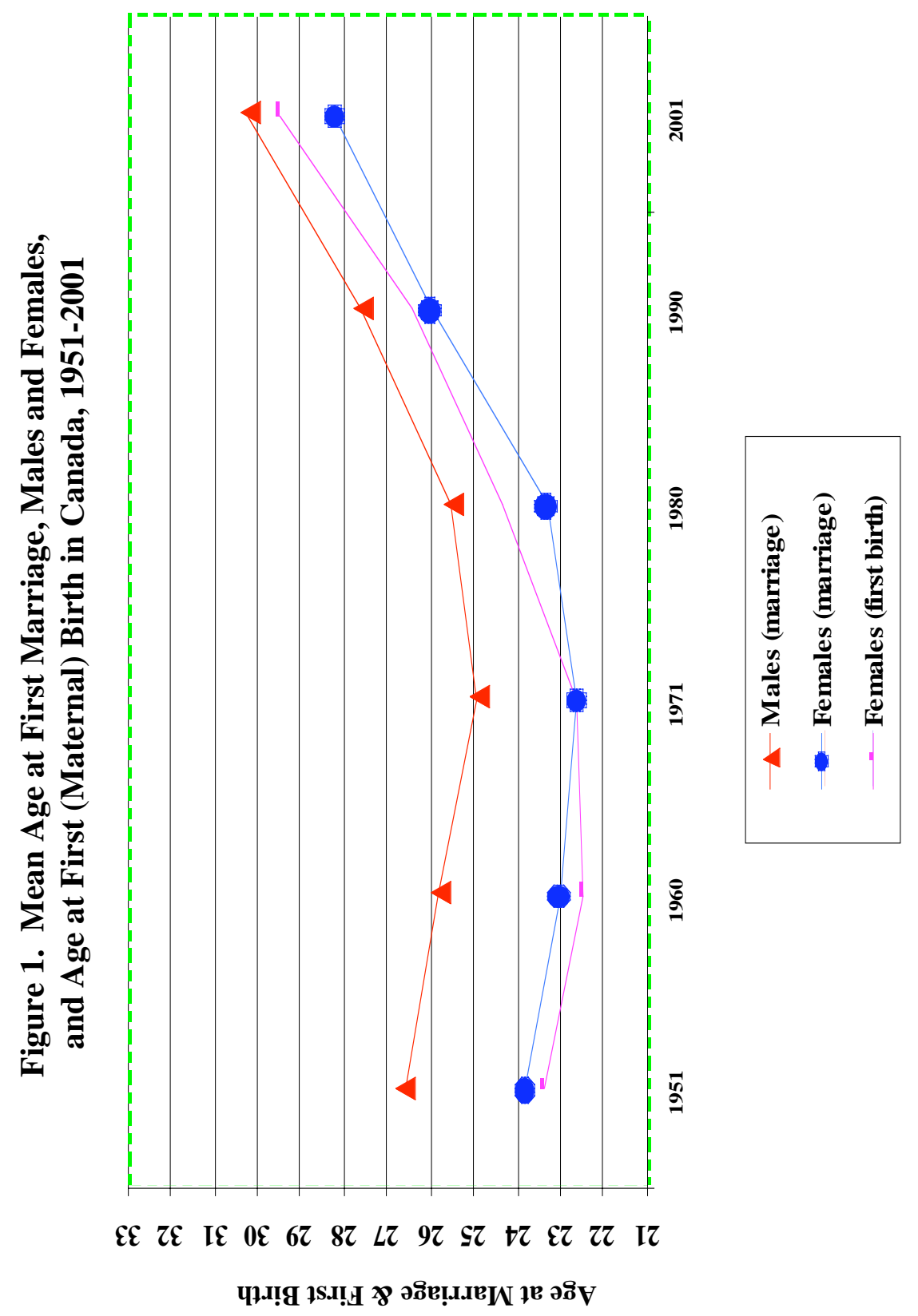

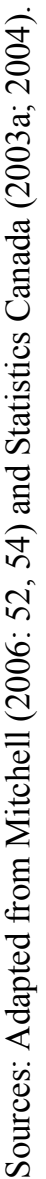


addition, Canada displays patterns similar to Britain (2.8), Sweden (2.39) and France (2.14) at 2.24, while divorce is the highest in the United States (3.80) and the lowest in Italy (.73), based on 2003 rates (a 2002 rate is provided for Canada since 2003 data are unavailable). Moreover, it is estimated that $37 \%$ of first marriages in Canada will end in divorce, whereas about $50 \%$ of all first marriages in the U.S. end in divorce (Cherlin, 1999).

It is also interesting to note that from a historical perspective, marriages often ended dissolved relatively early, although formal dissolution by divorce decree was not the usual circumstance underlying these situations. Instead, low mortality often "robbed" individuals of their partners at relatively early ages due to low life expectancy. Desertion by husbands also occurred, particularly during tough economic times (Gee, 2000).

Finally, it should be recognized that these changing patterns in family-related transitions to adulthood mask the considerable diversity that can occur within countries. For example, regardless of country of origin, women and those from lower socio-economic status backgrounds tend to enter transitional events earlier than males and those from higher socio-economic status. Moreover, regional differences are consistently found within most countries, due to differing employment opportunities, the location of educational institutions and local cultural or community environments (e.g., see Mitchell, 2006).

\section{Summary of Changing Family-Related Transitions to Adulthood and Implications for Intergenerational Relations}

These patterns establish that family-related transitions to adulthood in contemporary Canadian society and in many other industrialized nations have become extended and are subject to reversibility. These changes have restructured family life course schedules and created more flexibility and less permanence in the establishment of living arrangements and family formation behaviours relative to our $1950 \mathrm{~s}$ historical benchmark. As a result, intergenerational roles and responsibilities have altered over time, and this creates new challenges and opportunities for aging families. Notably, delays in youth transitions also delay parental counter-transitions, such as when they experience the empty nest, their children's marriage, and grandparenthood. Transition reversals (i.e., returning home and divorce) are also found to affect intergenerational relations, and they have the potential to create complexity or confusion, particularly when these behaviours are "institutionally incomplete" (Cherlin, 1978). 
The Boomerang Age from Childhood to Adulthood: Emergent Trends and Issues for Aging Families

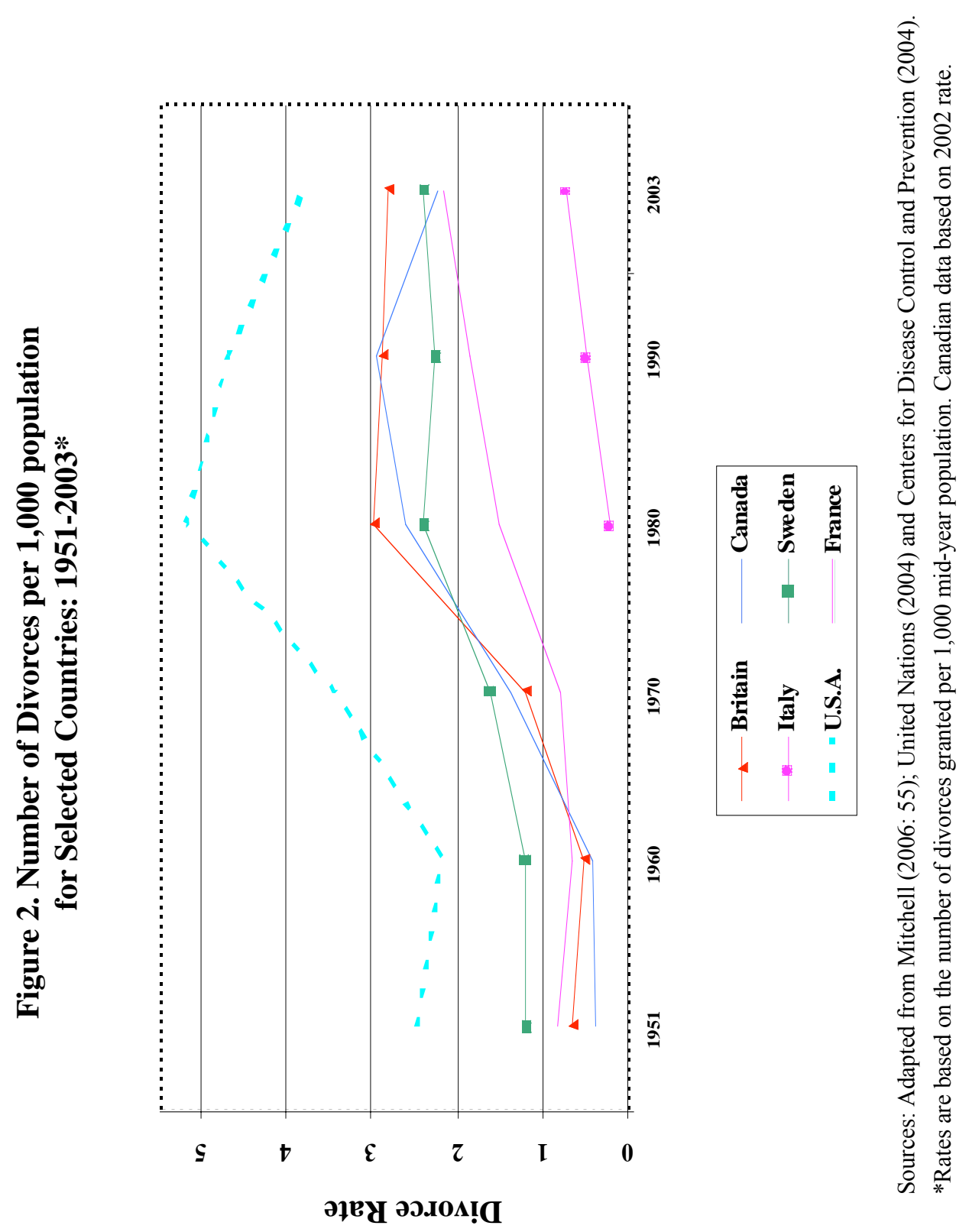


However, it is important to recognize that a longer-range historical view shows that family-related behaviours are subject to fluctuation or cyclical patterns. For example, high rates of intergenerational coresidence were witnessed in the 1930s and 1940s, such that the timing of the transition to the empty nest is once again occurring later in the family life cycle. Thus, these findings call into question the idea that modern-day family life is somehow "aberrant" -- and in crisis -- relative to family life of the past. In fact, with the exception of midtwentieth century family "modal" patterns, there may never have been a golden age of family stability (Gee, 2000). Nevertheless, changing social and economic environments suggest a number of emergent trends and issues for aging families of the future, a topic to which we now turn.

\section{Beyond the Boomerang Age: Emergent Trends and Issues for Aging Families}

The patterns previously described highlight how changing family-related behaviours of young adults and the extension of childhood affect intergenerational ties and aging family life. They also suggest a number of trends for aging families of the future. Yet, it is recognized that assuming current patterns will continue can be speculatively incorrect, given the fact that some family trends are short term and are tied to the economic climate of prosperity while others are non-linear and fluctuate over time (e.g., home leaving patterns). Furthermore, there are many unknowns, such as the future state of the economy or knowing what government will be in power in the future. Government actions can also affect family-related socio-demographic and economic realms, such as immigration policies. These policies influence the age, family composition, origin, and occupation of various segments of the population. Other state policies and programs can influence the decision-making of young people and their families through taxation, income distribution and service provision. Further, events such as widespread economic recessions, war and terrorist attacks, or natural disasters (including epidemics such as AIDS or Avian flu) are essentially unpredictable. Yet, these conditions or catastrophes could produce profound consequences for the timing of transitions to adulthood.

That being stated, there are important reasons to explore future projections of family trends. First, as family life course scholars and social demographers, we are interested in the influence of the past in shaping the present and future so that we can identify and assess current developments, and attempt to project their anticipated and unanticipated consequences. Moreover, these projected changes raise provocative questions and issues about the future for young people and of their families more generally. 
The Boomerang Age from Childhood to Adulthood:

Emergent Trends and Issues for Aging Families

\section{Economy, State and Schooling}

Although it is difficult to forecast what the state of the economy will be like in the near future, or which government will be in power, many commentators assert that the recent trend toward a retrenchment of the welfare state and the restructuring of the labour market in most industrialized societies (i.e., Sweden has a relatively strong social safety net) will continue and that this contributes to the prolongation of adult roles. This is because is parents must increasingly absorb the costs of providing housing and material support to the young adult generation and it decreases opportunities for disadvantaged groups (e.g., see Schoeni and Ross, 2005).

It is also commonly agreed that one trend that shows little sign of changing is the need for higher education. "Credentialism" or rising skill requirements account for the increasing educational inflation that we have witnessed. Since the 1990s, many professions now require more education, and high growthfields such as health care, education, technology, and other professional services require a college or university education. Educational attainment also affects the timing of transitional events and intergenerational relations. Young adults typically delay the formation of full-time work and family roles and responsibilities until they have completed their education. And in urban areas, living at home is a common strategy to save money while attending school, due to escalating tuition costs and the high cost of living (Turcotte, 2006).

In addition, changes to the labour market could mean that more young people will experience increasing uncertainty in the labour market. This is due to the expansion of the service sector (which often pays low wages), because there are fewer entry level "career" jobs, and since increasing number of workers change jobs or careers several times throughout their lives. Others will be employed in temporary or contractual jobs, with little job protection, low pay, and few benefits (Giele, 2004). Youth who do not obtain post-secondary credentials may therefore be particularly vulnerable to finding themselves in a revolving door of low paying and unstable jobs, which are often insufficient to support a family (Kerckhoff, 2002). And, as work lives become less permanent and unstable, young people may increasingly need to rely on their families of origin, such as by staying in parental homes longer as a strategy to save money and to delay their own family formation.

\section{Socio-Demographic, Cultural and Technological Shifts}

Turning to socio-demographic changes and their potential to influence the future lives of young people and their aging parents, one of the most significant 
changes in human history has been the recent explosion in population aging. This is the result of dramatic increases in longevity and decreases in fertility, which have caused age pyramids to become rectangularzed in most industrialized societies. Indeed, population aging is a global issue and there is concern about the long-term effects for family life (e.g., see Bengtson, Lowenstein, Putney and Gans, 2003). At present, Canada and the U.S. have about 13 percent of the population who are elderly (aged 65+), and these rates are expected to rise to between 21 and 23 percent by 2030 . Projected proportions are even higher for some European countries at between 24 to 26 percent (U.S. Census Bureau, 2002).

And although population aging is not expected to significantly impact the timing of future family-related transitions to adulthood, the lengthening of life is associated with the lengthening of the period of preparation for adulthood, as youth spend more time in school (Fussell and Furstenberg, 2005). Increased life expectancy also translates into extended length of family relationships. More years of "co-survivorship" between generations, for instance, means that more middle generation parents will be confronted with issues of elder care while providing financial and housing support to young adult children. At the same time, more aging parents and grandparents are now available for family continuity and stability across time (Silverstein, Girarrusso, and Bengtson, 1998).

It is also important to recognize future changes in immigration and the ethnic composition of a population, since many studies document key differences in family processes for certain racial and ethnic groups. For example, in 2001, Canada, Asian, Latin American and European-born parents were most likely to have adult children at home than Canadian-born parents (Turcotte, 2006). Young adults from certain ethnic groups (i.e., Indo-Canadian males) are also more likely to live in multi-generational households or to leave home at the time of marriage There is also a stronger filial responsibility and obligation to care for aging parents in many traditional ethnic groups (Gee and Mitchell, 2003; Mitchell, 2003; Mitchell, 2005).

The majority of recent Canadian immigrants (approximately 73\%) belong to what is euphemistically known as the visible minority population, and is defined by the Employment Equity Act as "persons, other than Aboriginal peoples who are non-Caucasian in race or non-white in colour." It is noteworthy that between 1981 and 2001, the visible minority population almost quadrupled from 1.1 million to nearly 4.0 million. This represents a change from $5 \%$ to $13 \%$ of the population in 20 years (Statistics Canada, 2003b). 
The Boomerang Age from Childhood to Adulthood:

Emergent Trends and Issues for Aging Families

The population of visible minority persons in Canada is expected to increase from about 4 million in 2001 to a level estimated between 6.3 million and 8.5 million in 2017, increases of $56 \%$ and $111 \%$ respectively (see Statistics Canada, 2005 for detailed population projections). In contrast, the remaining population (non-visible minority) is estimated to increase between $1 \%$ and $7 \%$ over the same period. This would mean that about 1 in 5 Canadians would be a visible minority in 2017 compared to 1 in 8 in 2001. And approximately 1 in 4 (between 21\% and 26\%) Canadians in 2017 will be foreign-born (immigrants). In 2017 about half of all visible minority persons will be South Asian or Chinese, an increase in population between 2001 and 2107 of about 2 million for each group. Blacks will remain the third largest group (about 1 million in 2017). The fastest growing visible minorities are the West Asian, Korean and Arab groups, more than doubling over that time period and ranging in size from about 200,000 to 425,000 in 2017.

Similarly, in the United States, future population projections show that the population of whites will shrink, while the percentages of other racial groups will expand (U.S. Census Bureau, 2004). In particular, the largest increases are expected among Asian Americans and Hispanics, both regarded as collectivist family cultures, with cultural traditions of extended coresidence and filial responsibility. And while there is variation among European countries in immigration patterns, it is expected that their immigrant policies will not be as 'pro-immigrant' compared to more migration-based countries such as Canada and the United States (Fussell, 2002).

Overall, high levels of immigration to North America are expected to contribute to more diverse and expanded meanings and patterns of "family." This is because many recent immigrants arrive from countries in which familism or family-centredness is operant. Thus, some young people will retain certain elements of their culture, such as disapproval of pre-marital residential independence, single parenthood, non-marital cohabitation, same-sex marriage (which became legal in Canada in 2005, with Bill C-38), and divorce, while others will adopt "mainstream" values (to varying degrees) that are less traditionally based.

Immigration patterns are also expected to contribute to greater linguistic diversification and the growth of certain religions, notably Muslim, Hindu and Sikh (Statistics Canada, 2005). The growth of these religions runs counter to the general trend toward secularization and the individualization of family lifecourses. However, there is no indication that a large-scale religious revival will occur in the near future, even though many immigrants are more religious than Canadian-born citizens (e.g., see Biles and Ibrahim, 2005). Moreover, the visible minority population is younger than the rest of the population, which means that 
they will experience age-related caregiving and employment issues at different points in time. Notably, it is expected that in 2017, the visible minority population will have a median age of 35.5 , about 8 years younger than the rest of the Canadian population (Statistics Canada, 2005).

With respect to fertility trends, some visible minority groups are expected to have more children than other groups. In particular, Black, Arab and Filipino have the highest fertility, whereas Chinese, Korean, and Japanese and West Asian visible minority groups have lower rates. However, these trends are not expected to significantly impact the general decline in fertility rates (Statistics Canada, 2005). Currently, fertility rates are below replacement level in Canada, the U.S. and most European countries. This shrinking supply of children has raised concerns over the future of the family, and particularly with respect to availability of kin to provide support to the older generation. However, Rosenthal (2000) counters this argument by documenting that the critical distinction in provisions of support is whether parents have at least one child versus none, and notes that the majority of individuals continue to have at least one child.

Moreover, the continuing entry of women into the paid labour force is expected to contribute to delays in marriage, parenthood and a rise in unattached women living alone. It is often suggested that this pattern also contributes to divorce, since women do not need to economically rely upon a partner to survive financially. Indeed, we are also witnessing more divorce in mid and later life, which creates more complexity (and diversity) in aging family relations. Further, women's participation in the paid labour force during mid-life can create a host of challenges with respect to their provision of support to coresident adult children and to elderly parents. And although many argue that the demands of the "sandwiched generation" have been exaggerated (e.g., see Rosenthal, 2000), there is rising concern that proportions facing these demands will increase over time and this will create more health, work, and financial-related challenges.

Finally, another significant and probably irreversible shift in the contours of family life is the revolution in medical, contraceptive and reproductive technology. Improvements in these areas are found to delay family transitional behaviours and can also improve the quality of our lives. In 2005, for example, there was a great deal of media attention on a 66 year old Romanian woman who became the oldest women in history to give birth. Other new reproductive methods increasingly permit child birth to occur later in the life course, which also delays counter transitions to grandparenthood. Moreover, advancements in communication technologies (i.e., video phones, email) are found to increasingly influence the quantity and quality of intergenerational contact, 
The Boomerang Age from Childhood to Adulthood:

Emergent Trends and Issues for Aging Families

although they do not affect the timing of family-related transitions to adulthood per se.

Thus, it is expected that while new technological advancements will not dramatically alter the family life courses of young adults in the near future, these improvements do have the capacity to allow individuals more choice with respect to certain family-related interactions and behaviours.

\section{Is the Boomerang Age Here to Stay? Summary and Conclusions}

Profound shifts have occurred in the developmental phase spanning childhood and adulthood in Canada and other Western industrialized nations. A prolonged period before "full adulthood," often occurring during the twenties and into the thirties, is now devoted to educational pursuits, job exploration, and experimentation with romantic relationships. Many young adults also increasingly rely on their parents for housing and economic support. As such, key markers and pathways into adulthood have become less predictable and linear and lend support to the idea that today's youth do experience a less standardized "package" of transitions relative to our mid-century benchmark.

However, a longer range historical perspective reinforces the need to situate changing trends within a wider pendulum of fluctuation, as well as themes of continuity, diversity, and social change. Indeed, family-related transitions to adulthood have never been universally predicable, an empirical fact that calls into question recent apocalyptic views of aging family life. They are also not uniform across all of the societies under study, which fails to support overgeneralized notions of a single, universal evolutionary trend toward individualization due to the forces of industrialization and modernization. Instead, it appears that we are moving more towards a scenario characterized by a modified individualism and increased diversification. This is due in part to the continuation of familistic behaviours among certain populations and sub-groups such as recent immigrants.

In conclusion, while it is virtually impossible to forecast family life in the future, there is little doubt that the family paths of young people will continue to evolve and transform. Indeed, while life courses are expected to become more individualized, flexible and diverse, they will likely retain or "boomerang" back to display traditional elements. This speculation is premised on the historical tendency for family-related behaviours to adulthood to persist and to shape, and re-shape through socio-demographic, socio-economic, cultural and technological change. Recent revolutions in these spheres have provided young people and their families with tremendous opportunities to form and delay family roles and 
However, it is important to recognize that a longer-range historical view shows that family-related behaviours are subject to fluctuation or cyclical patterns. For example, high rates of intergenerational coresidence were witnessed in the 1930s and 1940s, such that the timing of the transition to the empty nest is once again occurring later in the family life cycle. Thus, these findings call into question the idea that modern-day family life is somehow "aberrant" -- and in crisis -- relative to family life of the past. In fact, with the exception of midtwentieth century family "modal" patterns, there may never have been a golden age of family stability (Gee, 2000). Nevertheless, changing social and economic environments suggest a number of emergent trends and issues for aging families of the future, a topic to which we now turn.

\section{Beyond the Boomerang Age:}

\section{Emergent Trends and Issues for Aging Families}

The patterns previously described highlight how changing family-related behaviours of young adults and the extension of childhood affect intergenerational ties and aging family life. They also suggest a number of trends for aging families of the future. Yet, it is recognized that assuming current patterns will continue can be speculatively incorrect, given the fact that some family trends are short term and are tied to the economic climate of prosperity while others are non-linear and fluctuate over time (e.g., home leaving patterns). Furthermore, there are many unknowns, such as the future state of the economy or knowing what government will be in power in the future. Government actions can also affect family-related socio-demographic and economic realms, such as immigration policies. These policies influence the age, family composition, origin, and occupation of various segments of the population. Other state policies and programs can influence the decision-making of young people and their families through taxation, income distribution and service provision. Further, events such as widespread economic recessions, war and terrorist attacks, or natural disasters (including epidemics such as AIDS or Avian flu) are essentially unpredictable. Yet, these conditions or catastrophes could produce profound consequences for the timing of transitions to adulthood.

That being stated, there are important reasons to explore future projections of family trends. First, as family life course scholars and social demographers, we are interested in the influence of the past in shaping the present and future so that we can identify and assess current developments, and attempt to project their anticipated and unanticipated consequences. Moreover, these projected changes raise provocative questions and issues about the future for young people and of their families more generally. 
Barbara A. Mitchell

to decide among a variety of life options. At the same they, it is recognized that these changes can present new sets of challenges, particularly to those who lack family or institutional support, good health, educational resources, and financial power.

\section{Acknowledgements:}

*Mailing address: Dept. of Sociology/Anthropology, 8888 University Drive, Simon Fraser University, Burnaby, B.C., Telephone: 604-268-6629, Fax: 604291-5066, email: mitchelo@sfu.ca.

This paper is based on a keynote address presented at the $17^{\text {th }}$ Annual Warren E. Kalbach Population Conference, University of Alberta, 31 March, 2006.

\section{References:}

Beaupré, P. Declos, M. Milan and P. Turcotte. 2003. Junior is still at home: Trends and determinants in parental homeleaving in Canada. Paper presented at the Annual Meetings of the Canadian Population Society, Dalhousie University, Halifax, June.

Beck, U. 2000. "Living your own life in a runaway world: Individualization, globalization, and politics." In W. Hutton and A. Giddens (eds.), Global Capitalism (pp. 164-74). New York: New Press.

Bengtson, V.L. and K.R. Allen. 1993. "The life course perspective applied to families over time.” In W. Boss, R. Doherty, W. LaRossa, W. Schumm and S. Steinmetz (eds.), Sourcebook of Family Theories and Methods: A Contextual Approach (pp.469-499). New York: Plenum Press.

Bengtson, V.L., A. Lowenstein, N.M. Putney and D. Gans. 2003. "Global aging and the challenges to families." In V. L. Bengtson and A. Lowenstein (eds.), Global Aging and Challenges to Families (pp. 1-24). New York: Aldine de Gruyter.

Biles, J. and H. Ibrahim, H. 2005. "Religion and public policy: Immigration, citizenship, and multiculturalism - Guess who's coming to dinner?" In P. Bramadat and D. Seljak (eds.), Religion and Ethnicity in Canada (pp. 154-177). Toronto: Pearson. 
The Boomerang Age from Childhood to Adulthood:

Emergent Trends and Issues for Aging Families

Burton, L.M. and V.L. Bengston. 1985. "Black grandmothers: Issues of timing and continuity of roles." In V.L. Bengston and J.F. Roberston (eds.), Grandparenthood (pp. 61-77). Beverly Hills, CA: Sage.

Centers for Disease Control and Prevention. 2004. Births, marriages, divorces, and deaths: Provisional data for October 2003. National Vital Statistics Reports, Vol. 52, Number 18. U.S. Atlanta, Georgia: Department of Health and Human Services.

Cherlin, A. 1999. Public and Private Families: An Introduction, $2^{\text {nd }}$ ed. Boston: McGraw-Hill.

Cherlin, A. 1978. "Remarriage as an incomplete institution." American Journal of Sociology, 84: 634-650

Corijin, M. and E. Klijzing. (eds.). 2001. Transitions to Adulthood in Europe. Dordrecht: Klulwer Academic Publishers.

Elder, G.H., Jr. 2003. "The life course in time and place." In W.R. Heinz and V.W. Marshall (eds.), Social Dynamics of the Life Course: Transitions, Institutions, and Interrelations (pp. 57-71). New York: Aldine de Gruyter.

Elder, G.H., Jr. 1998. "The life course as developmental theory." Child Development, 69: 1-12.

Elder, G.H., Jr. 1995. "The life course paradigm: Social change and individual development." In P. Moen, G.H. Elder, Jr. and K. Luscher (eds.), Examining lives in context: Perspectives on the ecology of human development (pp. 101-139). Washington, D.C.: American Psychological Association.

Fields, J. and L.M. Casper. 2001. "America's families and living arrangements: Population characteristics. U.S. Census Bureau 2000," Current Population Reports, P20-537.

Fussell, E. 2002. "Youth in aging societies." In J.T. Mortimer and R.W. Larson (eds.), The Changing Adolescent Experience: Societal Trends and the Transition to Adulthood (pp. 18-51). New York: Cambridge University Press. 
Barbara A. Mitchell

Fussell, E. and F.F. Furstenberg. 2005. "The transition to adulthood during the twentieth century." In R.A. Settersten, F.F. Furstenberg, and R.G. Rumbaut (eds.), On the Frontier of Adulthood: Theory, Research, and Public Policy (pp. 29-75). Chicago: The University of Chicago Press

Gee, E.M. 2000. “Contemporary diversities.” In N. Mandell and A. Duffy (eds.), Canadian Families: Diversity, Conflict and Change, $2^{\text {nd }}$ ed. (pp. 78-111). Toronto: Harcourt Canada.

Gee, E.M. 1982. "Marriage in nineteenth century Canada." The Canadian Review of Sociology and Anthropology, 19: 311-325.

Gee, E.M. and G.M. Gutman. 2000. The Overselling of Population Aging: Apocalyptic Demography, Intergenerational Challenges, and Social Policy. Toronto: Oxford University Press.

Gee, E.M. and B.A. Mitchell. 2003. "One roof: exploring multi-generational households in Canada." In M. Lynn (ed.), Voices: Essays on Canadian Families, $2^{\text {nd }}$ ed. (pp. 293-313). Toronto: Thomson Nelson.

Giele, J.Z. 2004. "Women and men as agents of change in their own lives." In J.Z. Giele and E. Holst (eds.), Changing Life Patterns in Western Industrial Societies (pp. 299-316). New York: Elsevier Jai.

Giele, J.Z. and G.H.. Elder, Jr. 1998. Methods of Life Course Research: Qualitative and Quantitative Approaches. Thousand Oaks, Calif: Sage Publications.

Goldscheider, F. and C. Goldscheider. 1999. The Changing Transition to Adulthood: Leaving and Returning Home. Thousand Oaks: Sage Publications.

Hagestad, G.O. 1991. "Dilemmas in life course research: An international perspective." In W.R. Heinz (ed.), Theoretical Advances in Life Course Research (pp. 23-57). Bremen: Deutscher Studien Verlag.

Hareven, T.K. (ed.) 1996. Aging and Generational Relations: Life-course and Cross-Cultural Perspectives. New York: Aldine de Gruyter.

Kerckhoff, A.C. 2002. "The transition from school to work." In J.T. Mortimer and R.W. Larson (eds.), The Changing Adolescent Experience: Societal Trends and the Transition to Adulthood (pp. 52-87). New York: Cambridge University Press. 
The Boomerang Age from Childhood to Adulthood:

Emergent Trends and Issues for Aging Families

Marshall, V.W. and M.M. Mueller. 2003. "Theoretical roots of the life-course perspective." In W. R. Heinz and V.W. Marshall (eds.), Social Dynamics of the Life Course: Transitions, Institutions and Interrelations (pp. 3-32). New York: Aldine de Gruyter

Mitchell, B.A. 2006. The Boomerang Age: Transitions to Adulthood in Families. New Brunswick, NJ: Aldine-Transaction.

Mitchell, B.A. 2005. "Canada's growing visible minority population: Generational challenges, opportunities and federal policy considerations." Discussion papercommissioned by The Multicultural Program, Dept. of Canadian Heritage, Gatineau, Quebec, pp. 51-62 (also a French version).

Mitchell, B.A. 2003. "Would I share a home with an elderly parent? Exploring ethnocultural diversity and intergenerational support relations during young adulthood.” Canadian Journal on Aging, 22(1): 69-82.

Mortimer, J.T. and R.W. Larson. 2002. "Macrostructural trends and the reshaping of adolescence." In J.T. Mortimer and R.W. Larson (eds.), The Changing Adolescent Experience: Societal Trends and the Transition to Adulthood (pp. 1-17). New York: Cambridge University Press.

Pike, R. and Allen, C. 2002. "Mamma mia," Guardian, May 14.

Ravenera, Z.R., F. Rajulton, and T.K. Burch. 1992. A cohort analysis of homeleaving in Canada, 1910-1975. Paper presented at the Annual Meetings of the Canadian Population Society, Charlottetown, PEI, June.

Rosenthal, C. 2000. "Aging families: Have current changes and challenges been 'oversold?" In Gee, E.M. and G.M. Gutman, The Overselling of Population Aging: Apocalyptic Demography, Intergenerational Challenges, and Social Policy (pp. 45-63). Toronto: Oxford University Press.

Schoeni, R.f. and K.E. Ross. 2005. "Material assistance from families during the transition to adulthood." In R.A. Settersten, F.F. Furstenberg, and R.G. Rumbaut (eds.), On the Frontier of Adulthood: Theory, Research, and Public Policy (pp. 396-416). Chicago: The University of Chicago Press. 
Barbara A. Mitchell

Settersten, R.A., Jr. 2005. "Social policy and the transition to adulthood: Toward stronger institutions and individual capacities." In R.A. Settersten, F.F. Furstenberg, and R.G. Rumbaut (eds.), On the Frontier of Adulthood: Theory, Research, and Public Policy (pp. 534-560). Chicago: The University of Chicago Press.

Settersten, R.A., Jr., F.K. Furstenberg, Jr. and R.G. Rumbaut. 2005. On the Frontier of Adulthood: Theory, Research, and Public Policy. Chicago: The University of Chicago Press.

Silverstein, M., Giarrusso, R., and V.L. Bengtson. 1998. "Intergenerational solidarity and the grandparent role." In M. Szinovacz (ed.), Handbook on Grandparenthood (pp. 144-58). Westport, CT: Greenwood.

Statistics Canada. 2005. Population Projections of Visible Minority Groups, Canada, Provinces and Regions, 2001-2017. Catalogue No. 91-541-XIE. Ottawa: Minister of Industry.

Statistics Canada. 2004. Births, 2002. The Daily, Monday, April 19.

Statistics Canada. 2003a. Marriage, The Daily, Thursday, February 6.

Statistics Canada. 2003b. Canada's Ethnocultural Portrait: The Changing Mosaic. Ottawa: Minister of Industry

Statistics Canada. 2002. 2001 Census: Profile of Canadian families and Households: Diversification Continues. Census release 22 October, 2002, www.statcan.ca.

Turcotte, M. 2006. "Parents with adult children living at home." Canadian Social Trends, Catalogue No. 11-008 (Spring): 2-10.

U.S. Census Bureau. 2004. "U.S. interim projections by age, sex, race, and Hispanic origin," http://www.census.gov/ipc/www/usinterimproj/March $\underline{18}, 2004$.

U.S. Census Bureau. 2002. "International data base,” http://blue.census.gov/cgibin/ipc/idbagg, July 30, 2005.

Vanier Institute of the Family. 2002. Profiling Canada's Families. III. Ottawa: Vanier Institute of the Family. 
The Boomerang Age from Childhood to Adulthood: Emergent Trends and Issues for Aging Families

Wu, Z. and C.M. Schimmele. 2003. "Cohabitation.” In J.J. Ponzetti (ed.), The International Encyclopedia of Marriage and Family Relationships, $2^{\text {nd }}$ ed. (pp. 315-323). New York: Macmillan Reference, USA. 